\title{
ANALISIS PERBANDINGAN PENDAPATAN USAHATANI KENTANG SEBELUM DAN PADA MASA PANDEMI COVID-19 DI KECAMATAN KERTASARI, KABUPATEN BANDUNG
}

\author{
ANALYSIS COMPARISON OF POTATO FARMING INCOME BEFORE AND \\ DURING THE PANDEMIC COVID-19 \\ IN KERTASARI SUB DISTRICT BANDUNG DISTRICT
}

Widia Kintan Sabila Firdaus*, Eliana Wulandari, Dini Rochdiani, Zumi Saidah

Universitas Padjadjaran, Jatinangor

*E-mail: Widiafirdaus03@gmail.com

(Diterima 22-02-2021; Disetujui 03-06-2021)

\begin{abstract}
ABSTRAK
Kentang merupakan tanaman sayuran semusim yang dapat menggantikan bahan pangan pokok. Kebutuhan kentang yang semakin meningkat membuat mayoritas petani di Kecamatan Kertasari menanam kentang sebagai salah satu komoditas pertaniannya. Masa pandemi Covid-19 berdampak terhadap sektor pertanian, seperti penurunan harga jual produk pertanian yang juga terjadi pada komoditas kentang. Penelitian ini bertujuan untuk menganalisis pendapatan usahatani kentang sebelum dan pada masa pandemi Covid-19 di Kecamatan Kertasari. Penelitian ini menggunakan desain penelitian kuantitatif dengan menggunakan kuesioner sebagai instrumen penelitian. Lokasi penelitian dilakukan di Desa Cibeureum dan Desa Cikembang di Kecamatan Kertasari pada 44 petani kentang pada bulan Agustus-November 2020. Analisis data dalam penelitian ini menggunakan analisis pendapatan, analisis $\mathrm{R} / \mathrm{C}$ dan uji paired sample t-test. Hasil penelitian menunjukkan bahwa terdapat perbedaan yang signifikan antara pendapatan usahatani kentang sebelum masa pandemi Covid-19 dan pada masa pandemi Covid-19, serta memiliki nilai R/C lebih dari 1 yang artinya usahatani kentang di Kecamatan Kertasari menguntungkan dan layak untuk diusahakan.
\end{abstract}

Kata Kunci: Kentang, Pendapatan Usahatani, Pandemi Covid-19

\section{ABSTRACT}

Potato is an annual vegetable crop that can replace staple food. The increase of potatoes needs lead to the majority of farmers in Kertasari to grow potatoes as one of their agricultural commodities. The Covid-19 pandemic had an impact on the agricultural sector, such as a decrease in the selling price of agricultural products which also occurred in potato. This study aimed to analyze the income of potato farming before and during the Covid-19 pandemic in Kertasari. This study uses a quantitative research design using a questionnaire as a research instrument. The research was conducted in Cibeureum and Cikembang Villages in Kertasari to 44 potato farmers from August to November 2020. Data analysis in this study used income analysis, $R / C$ analysis, and paired sample t-test. The result showed that there was a significant difference between the income of potato farming before the Covid-19 pandemic and during the Covid-19 pandemic, and had a value of $R / C$ above 1 indicating that potato farming in Kertasari is profitable and feasible to be performed.

Keywords: Potato, Farm Income, The Pandemic Of Covid-19 


\section{PENDAHULUAN}

Pada tahun 2020, kemunculan wabah virus jenis baru yaitu corona virus adalah virus jenis baru SARS-CoV-2 (Severe acute respiratory syndrome coronavirus-2) yang menyebabkan penyakit Covid-19 (Coronavirus disease 2019) (Yuliana, 2020). Penyebaran penyakit Covid-19 di Indonesia sangat cepat sehingga dilakukan pembatasan sosial berskala besar pada tanggal 11 April 2020 di beberapa wilayah di Indonesia yang salah satunya adalah Provinsi Jawa Barat (Kementerian Kesehatan Republik Indonesia, 2020).

Dampak dari wabah tersebut bukan hanya pada sektor kesehatan. Menurut FAO (2020), efek pandemi Covid-19 mempengaruhi pada sisi penawaran di sektor pertanian yaitu terjadinya guncangan harga. Fluktuasi harga akan berdampak terhadap penerimaan usahatani dan keuntungan yang didapatkan petani dalam usahatani (Sukmawati dkk, 2016).

Kentang merupakan salah satu komoditas sayuran yang memiliki kandungan gizi karbohidrat utama sehingga kentang berpotensi dalam diversifikasi pangan yaitu dengan menggantikan bahan pangan pokok seperti gandum, jagung maupun beras
(Muhibuddin, 2016). Seiring dengan pertumbuhan penduduk, permintaan masyarakat terhadap kentang juga meningkat (Mardawati, 2013), yang ditandai dengan meningkatnya rata - rata konsumsi kentang per kapita per tahun di Indonesia dari tahun 2014 hingga 2018 sebesar 54,6\% (Kementerian Pertanian, 2019). Oleh karena itu, kentang memiliki potensi untuk dikembangkan. Perkembangan rata-rata konsumsi per kapita per tahun di Indonesia tahun 20142018 disajikan pada Gambar 1.

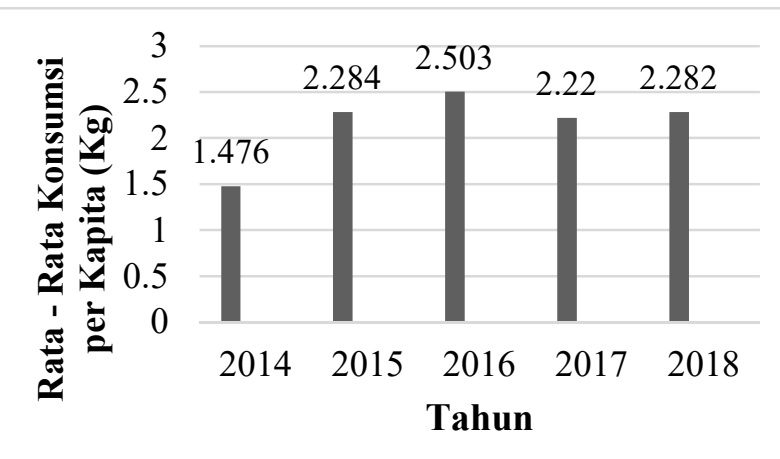

Gambar 1. Perkembangan Rata-rata Konsumsi per Kapita per Tahun di Indonesia Tahun 2014-2018

Sumber: Kementerian Pertanian Republik Indonesia, 2019

Perkembangan jumlah produksi kentang di Indonesia mengalami fluktuasi setiap tahunnya, namun memiliki ratarata produksi yang cukup besar yaitu sebesar 1.220.850 ton/tahun (Rahmah \& Wulandari, 2020). Sentra produksi kentang dengan jumlah produksi tertinggi di Indonesia adalah Jawa Barat, Sumatera Utara dan Jawa Tengah. Ketiga sentra 
utama kentang tersebut menyumbang rata-rata $80 \%$ dari produksi total per tahun (Muhibuddin, 2016). Perkembangan jumlah produksi kentang tahun 2016 hingga 2018 di Jawa Barat memiliki rata-rata produksi sebesar 277.070 ton per tahun (Rahmah \& Wulandari, 2020).

Fluktuasi harga yang tinggi sering terjadi pada komoditas hortikultura seperti kentang, kol, cabe dan tomat (Apriadi \& Saputra, 2017). Harga ratarata kentang di Jawa Barat dan Indonesia tahun 2016-2018 disajikan pada Tabel 1.

Tabel 1. Harga rata-rata kentang di Jawa Barat dan Indonesia Tahun 20162018

\begin{tabular}{ccc}
\hline Tahun & $\begin{array}{c}\text { Harga Indonesia } \\
\text { (Rp) }\end{array}$ & $\begin{array}{c}\text { Harga Jawa } \\
\text { Barat (Rp) }\end{array}$ \\
\hline $\mathbf{2 0 1 6}$ & $10.127,2$ & $8.265,4$ \\
$\mathbf{2 0 1 7}$ & $11.097,3$ & $7.836,7$ \\
$\mathbf{2 0 1 8}$ & $10.906,5$ & 7.955 \\
\hline Sumber: Badan Pusat Statistik (2019)
\end{tabular}

Sumber: Badan Pusat Statistik (2019)

Berdasarkan Tabel 1, harga komoditas kentang di Jawa Barat mengalami fluktuasi harga kentang yang cenderung mengalami penurunan sebesar 3,7\%. Rata-rata harga kentang di Jawa Barat pada tahun 2016 hingga 2018 adalah sebesar Rp.8.019,- per kg. Tidak stabilnya harga produsen berdampak terhadap prospek bisnis usahatani dan perhitungan laba rugi dalam usahatani (Rahmah \& Wulandari, 2020).

Pada umumnya kentang dibudidayakan di daerah pegunungan atau daratan tinggi (Muhibuddin, 2016) seperti di Kecamatan Kertasari, Jawa Barat yang terletak pada ketinggian 1.200-1.800 m dari permukaan laut. Jenis varietas kentang yang dikembangkan oleh petani kentang di Kecamatan Kertasari adalah kentang atlantik dan granola. Petani kentang yang menanam jenis kentang atlantik merupakan petani yang menjalin kemitraan atau kontrak dengan PT. Indofood Fritolay Makmur. Kemitraan tersebut memiliki kontrak yang telah disepakati yaitu kontrak harga per kilogram dan pemasaran hasil produksi kentang yang seluruhnya dipasarkan ke PT. Indofood Fritolay Makmur. Pada tahun 2020 harga kentang tersebut adalah sebesar Rp7.200 per kg yang mengalami kenaikan dari Rp.7.000 per kg pada tahun 2018. Berbeda halnya dengan petani kentang yang membudidayakan kentang jenis granola, petani tersebut tidak memiliki kontrak dengan perusahaan sehingga harga jual kentang memiliki ketidakpastian. Apabila harga jual kentang sedang mengalami peningkatan maka petani kentang akan mengalami keuntungan, apabila harga jual kentang sedang mengalami penurunan maka petani kentang akan mengalami kerugian. 
Menurut Kabupaten Bandung dalam Angka (2019), pada tahun 2017

Kecamatan Kertasari memiliki rata-rata produksi tertinggi ke dua setelah Kecamatan Pangalengan yaitu sebesar 215,86 kw per hektar. Jumlah produksi kentang yang tinggi tersebut tidak dapat menjamin keuntungan yang didapatkan oleh petani apabila harga kentang pada masa pandemi Covid-19 mengalami fluktuasi yang tentunya akan mempengaruhi pendapatan usahatani kentang. Harga kentang yang cenderung berfluktuasi namun komoditas kentang tetap menjadi komoditas utama. Menurut Puspasari dkk (2013), kontribusi pendapatan petani dari usahatani kentang terhadap pendapatan rumah tangga yaitu sebesar $69,7 \%$ dan $25 \%$ didapat dari usahatani tanaman semusim lainnya seperti kubis, wortel dan bawang daun. Pendapatan usahatani kentang sangat penting bagi petani kentang untuk memenuhi kebutuhan keluarganya, fluktuasi harga jual selalu terjadi pada komoditas pertanian termasuk kentang pada sebelum masa pandemi Covid-19 maupun pada masa pandemi Covid-19 Oleh karena itu, perlu dilakukan penelitian mengenai perbandingan pendapatan usahatani kentang sebelum masa pandemi Covid-19 dan pada masa pandemi Covid-19 di Kecamatan Kertasari, Kabupaten Bandung.

\section{METODE PENELITIAN}

Penelitian ini dilakukan di Kecamatan Kertasari, Kabupaten Bandung pada bulan Agustus-November 2020. Kecamatan Kertasari adalah sentra produksi kentang terbesar kedua di Kabupaten Bandung. Jenis penelitian yang digunakan adalah penelitian kuantitatif. Penelitian dengan pendekatan kuantitatif merupakan pengumpulan jenis data-data yang dapat dikuantitatifkan dan data tersebut diolah menggunakan teknik statistik (Yusuf, 2014).

Pengumpulan data dalam penelitian ini menggunakan metode wawancara, kuisioner, wawancara serta studi kepustakaan. Sumber data yang digunakan adalah data sekunder dan data primer. Data sekunder diperoleh melalui instansi terkait yaitu BPS, Kementrian Pertanian, Dinas Pertanian Tanaman Pangan Kabupaten Bandung dan Kantor Kecamatan Kertasari, dan instansi terkait lainnya yang relevan dengan penelitian ini. Data primer diperoleh dari lokasi penelitian yaitu melalui pengisian kuesioner terhadap 44 responden dari Desa Cikembang dan Desa Cibeureum yang memiliki produksi kentang tertinggi 
di Kecamatan Kertasari. Penarikan sampel pada penelitian ini menggunakan teknik Stratified Random Sampling.

Metode analisis data yang digunakan adalah analisis biaya usahatani untuk menganalisis biaya total yang dikeluarkan usahatani kentang dalam satu musim. Berikut ini merupakan analisis biaya usahatani dalam penelitian ini berdasarkan Suratiyah (2015):

$$
\mathbf{T C}=\mathbf{F C}+\mathrm{VC}
$$

Keterangan:

TC: Biaya total usahatani kentang (Rp)

FC: Biaya tetap usahatani kentang (Rp)

VC: Biaya variabel usahatani kentang (Rp)

Analisis penerimaan yang digunakan untuk menganalisis pendapatan kotor usahatani kentang. Berikut ini merupakan penerimaan dalam penelitian ini berdasarkan Suratiyah (2015):

$$
\mathbf{T R}=\mathbf{P} \times \mathbf{Y}
$$

Keterangan:

TR: Penerimaan total usahatani kentang (Rp)

P: Harga jual kentang per kg (Rp)

Y: Total produksi kentang $(\mathrm{kg})$

Analisis pendapatan yang digunakan untuk menganalisis pendapatan bersih yang diterima oleh petani dalam mengusahakan kentang.
Berikut persamaan pendapatan dalam penetilian ini berdasarkan Suratiyah (2015):

$$
\mathbf{I}=\mathbf{T R}-\mathbf{T C}
$$

Keterangan:

$\mathrm{I}=$ Pendapatan bersih usahatani kentang (Rp)

$\mathrm{TR}=$ Penerimaan usahatani kentang $(\mathrm{Rp})$

$\mathrm{TC}=$ Biaya total produksi yang dikeluarkan dalam usahatani kentang (Rp).

Uji paired sample t-test digunakan untuk menganalisis perbedaan rata-rata pendapatan usahatani kentang sebelum masa pandemi Covid-19 dan pada masa pandemi Covid-19. Berikut merupakan rumus uji paired sample t-test dalam penelitian ini:

$$
\mathbf{t}_{\text {hit }}=\frac{\bar{D}}{\frac{S D}{\sqrt{n}}}
$$

Keterangan:

$\mathrm{t}=$ Nilai $\mathrm{t}$ hitung

$\overline{\mathrm{D}}=$ Rata-rata selisih rata-rata dari pendapatan sebelum masa pandemi Covid-19 dan pada masa pandemi Covid19

$\mathrm{SD}=$ Standar deviasi selisih pendapatan sebelum masa pandemi Covid-19 dan pada masa pandemi Covid-19 $\mathrm{n}=$ Jumlah sampel

Penentuan hipotesisnya yaitu $\mathrm{H}_{0}$ : tidak terdapat perbedaan yang signifikan antara pendapatan usahatani kentang 
pada masa pandemi Covid-19 dan pada sebelum masa pandemi Covid-19, dan $\mathrm{H}_{1}$ : terdapat perbedaan yang signifikan antara pendapatan usahatani kentang pada masa pandemi Covid-19 dan sebelum masa pandemi Covid-19. Kriteria uji atau pengambilan keputusan yaitu apabila nilai $t_{\text {hitung }}>t_{\text {tabel }}$ atau nilai Sig. $<0,05$ maka artinya terdapat perbedaan antara pendapatan usahatani kentang pada saat sebelum pandemi Covid-19 dan pada masa pandemi Covid19 dan apabila nilai $t_{\text {hitung }}<t_{\text {tabel }}$ atau nilai Sig. $>0,05$ maka artinya tidak terdapat perbedaan antara pendapatan usahatani kentang pada sebelum mada pandemi Covid-19 dan pada masa pandemi Covid-19.

Analisis Return Cost Ratio (R/C) digunakan untuk mengetahui kondisi usahatani yang dijalankan pada saat sebelum masa pandemi Covid-19 dan pada masa pandemi Covid-19 tersebut untung atau rugi. Secara matematis dapat dijelaskan sebagai berikut:

$$
\mathbf{R} / \mathbf{C}=\frac{\text { Penerimaan }(R p)}{\text { Total Biaya Produksi }(\mathbf{R p})}
$$

Kriteria pengambilan keputusan dari hasil analisis $\mathrm{R} / \mathrm{C}$ yaitu apabila nilai $\mathrm{R} / \mathrm{C}>1$ maka usahatani tersebut untung, nilai $\mathrm{RC}<1$ maka usahatani tersebut rugi, dan nilai $\mathrm{RC}=1$ maka usahatani tersebut tidak untung dan tidak rugi.

\section{HASIL DAN PEMBAHASAN}

\section{Penerimaan Usahatani Kentang}

Penerimaan usahatani kentang merupakan hasil dari jumlah hasil produksi usahatani kentang yang dikalikan dengan harga jual (Herliani dkk, 2019).

Penerimaan usahatani kentang sebelum masa pandemi Covid-19 dan pada masa pandemi Covid-19 disajikan pada Tabel 2.

Tabel 2. Penerimaan Usahatani Kentang

\begin{tabular}{ccc}
\hline $\begin{array}{c}\text { Komponen } \\
\text { Penerimaan }\end{array}$ & $\begin{array}{c}\text { Sebelum Masa } \\
\text { Pandemi } \\
\text { Covid-19 }\end{array}$ & $\begin{array}{c}\text { Masa } \\
\text { Pandemi } \\
\text { Covid-19 }\end{array}$ \\
\hline $\begin{array}{c}\text { Jumlah Produksi } \\
\text { (Kg) }\end{array}$ & 20.590 & 19.275 \\
Harga Jual (Rp) & 7.773 & 6.918 \\
\hline $\begin{array}{c}\text { Penerimaan } \\
\text { (Rp/ha/MT) }\end{array}$ & $\mathbf{1 6 0 . 0 4 6 . 0 7 0}$ & $\mathbf{1 3 3 . 3 4 4 . 4 5 0}$ \\
\hline
\end{tabular}

Sumber: Data Primer, 2020

Berdasarkan hasil penelitian dapat diketahui bahwa penerimaan usahatani kentang sebelum masa pandemi Covid-19 adalah sebesar Rp160.046.070/ha/MT sedangkan pada masa pandemi Covid-19 mengalami penurunan menjadi Rp133.344.450/ha/MT, hal tersebut dikarenakan jumlah produksi kentang dan harga jual kentang yang menurun.

Dampak pandemi Covid-19 pada usahatani kentang di Kecamatan Kertasari yaitu terjadi penurunan harga jual kentang dari Rp7.773/kg sebelum masa pandemi Covid-19 dan Rp6.918/kg pada masa pandemi Covid-19. Menurut 
Rahmah \& Wulandari (2020), apabila harga jual rendah maka petani akan mengalami kerugian.

Jumlah produksi pada masa pandemi Covid-19 terjadi penurunan yaitu $19.275 \mathrm{~kg} / \mathrm{ha}$ dari $20.590 \mathrm{~kg} / \mathrm{ha}$ pada sebelum masa pandemi Covid-19. Menurut Ernawati dkk (2015), perbedaan jumlah produksi yang dihasilkan disebabkan perbedaan kualitas penggunaan sarana produksi pertanian, luas lahan yang dimiliki oleh petani, serta kegiatan pengelolaan usahatani kentang seperti pemeliharaan tanaman kentang. Jumlah produksi kentang yang menurun tersebut dikarenakan mayoritas petani kentang menggunakan Varietas Granola generasi ke-3 (G3) dan Varietas Granola generasi ke-4 (G4), sedangkan sebelum masa pandemi Covid-19 petani kentang menggunakan Varietas Granola generasi ke-2 (G2) dan generasi pertama (G1). Menurut Mulyono dkk (2017), semakin awal generasi bibit maka semakin baik kualitas bibit karena dapat menghasilkan jumlah produksi yang lebih banyak. Penggunaan bibit generasi berikutnya pada masa pandemi Covid-19 tersebut dikarenakan petani ingin menurunkan biaya produksi usahatani kentang. Menurut Amarullah dkk (2019), sebagian besar petani menggunakan bibit generasi berikutnya disebabkan mahalnya harga kentang bibit bermutu yang menyebabkan rendahnya produktivitas kentang. Sejalan dengan itu, menurut Rahmadona dkk (2015), dalam ekonomi pertanian pendapatan yang tinggi tidak bermakna apabila memiliki jumlah biaya produksi yang besar.

\section{Biaya Usahatani Kentang}

Menurut Suratiyah (2015), biaya usahatani merupakan pengeluaran yang dipergunakan dalam usahatani. Biaya usahatani kentang terdiri dari biaya tetap dan biaya variabel. Biaya usahatani kentang sebelum masa pandemi Covid-19 dan pada masa pandemi Covid-19 disajikan pada Tabel 3.

Berdasarkan Tabel 3 menunjukkan biaya usahatani kentang sebelum masa pandemi Covid-19 lebih besar dibandingkan dengan pada masa pandemi Covid-19. Perbedaan tersebut dikarenakan pada masa pandemi Covid19 petani kentang di Kecamatan Kertasari menggunakan bibit dengan varietas G3 hingga G4 sehingga mengeluarkan biaya sebesar Rp.31.971.030/ha/MT serta penggunaan tenaga kerja di masa pandemi Covid-19 lebih sedikit dibandingkan dengan sebelum terjadinya masa pandemi Covid-19. 
Tabel 3. Biaya Usahatani Kentang

\begin{tabular}{|c|c|c|}
\hline Komponen Biaya & $\begin{array}{c}\text { Jumlah Pada } \\
\text { Sebelum Masa } \\
\text { Pandemi } \\
\text { Covid-19 } \\
\end{array}$ & $\begin{array}{c}\text { Jumlah } \\
\text { Pada Masa } \\
\text { Pandemi } \\
\text { Covid-19 } \\
\end{array}$ \\
\hline \multicolumn{3}{|l|}{ A.Biaya Tetap } \\
\hline Penyusutan Alat & 1.214 .023 & 1.214 .023 \\
\hline $\begin{array}{l}\text { PBB (Pajak Bumi } \\
\text { dan Bangunan) }\end{array}$ & 150.500 & 147.896 \\
\hline Sewa Lahan & 2.181 .961 & 1.859 .664 \\
\hline Bunga Pinjaman & 3.883 .333 & 2.481 .746 \\
\hline Total Biaya Tetap & 7.379.817 & 5.703.329 \\
\hline \multicolumn{3}{|l|}{ B.Biaya Variabel } \\
\hline Bibit & 32.208 .000 & 31.971 .030 \\
\hline Pupuk Organik & 8.168 .432 & 8.802 .450 \\
\hline Pupuk Anorganik & 8.657 .275 & 9.076 .225 \\
\hline Pestisida & 11.036 .931 & 11.842 .552 \\
\hline Tenaga Kerja & 37.043 .862 & 34.876 .948 \\
\hline Bensin & 1.722 .435 & 1.597 .260 \\
\hline Ajir & 3.156 .736 & 3.354 .032 \\
\hline Tali & 1.460 .800 & 1.548 .448 \\
\hline Mulsa & 4.550 .000 & 4.550 .000 \\
\hline $\begin{array}{l}\text { Total Biaya } \\
\text { Variabel }\end{array}$ & 108.004 .472 & 107.618 .945 \\
\hline $\begin{array}{l}\text { Biaya Total } \\
\text { Usahatani } \\
\text { Kentang } \\
\text { (Rp/ha/MT) }\end{array}$ & 115.384.289 & 113.322.274 \\
\hline
\end{tabular}

Pendapatan Usahatani Kentang

Pendapatan usahatani kentang merupakan hasil dari pengurangan penerimaan usahatani kentang dengan biaya total usahatani kentang. Pendapatan usahatani kentang sebelum masa pandemi Covid-19 dan pada masa pandemi Covid19 disajikan pada Tabel 4.

Tabel 4. Pendapatan Usahatani Kentang

\begin{tabular}{ccc}
\hline $\begin{array}{c}\text { Komponen } \\
\text { Pendapatan }\end{array}$ & $\begin{array}{c}\text { Sebelum Masa } \\
\text { Pandemi } \\
\text { Covid-19 }\end{array}$ & $\begin{array}{c}\text { Masa } \\
\text { Pandemi } \\
\text { Covid-19 }\end{array}$ \\
\hline $\begin{array}{c}\text { Penerimaan } \\
\text { (Rp) }\end{array}$ & 160.046 .070 & 133.344 .450 \\
$\begin{array}{c}\text { Biaya Total } \\
\text { (Rp) }\end{array}$ & 115.384 .289 & 113.322 .274 \\
\hline $\begin{array}{c}\text { Pendapatan } \\
\text { (Rp/ha/MT) }\end{array}$ & $\mathbf{4 4 . 6 6 1 . 7 8 1}$ & $\mathbf{2 0 . 0 2 2 . 1 7 6}$ \\
\hline
\end{tabular}

Sumber: Data Primer, 2020
Berdasarkan Tabel 4, pendapatan usahatani kentang sebelum masa pandemi Covid-19 lebih besar dibandingkan pada masa pandemi Covid-19. Hal tersebut dikarenakan penerimaan usahatani kentang pada masa pandemi Covid-19 yang rendah sehingga menurunkan pendapatan usahatani kentang.

\section{Hasil Analisis Uji Paired Sample T-Test}

Hasil analisis uji paired sample ttest menunjukkan perbedaan pendapatan usahatani petani kentang sebelum masa pandemi Covid-19 dan pada masa pandemi Covid-19. Pada pembahasan sebelumnya, hasil analisis pendapatan usahatani kentang sebelum masa pandemi Covid-19 dan pada masa pandemi Covid19 berbeda. Rata-rata pendapatan usahatani kentang sebelum masa pandemi Covid-19 lebih tinggi. Berikut merupakan hasil uji paired sample t-test menggunakan software SPSS untuk mengetahui signifikansi perbedaan pendapatan usahatani kentang sebelum masa pandemi Covid-19 dan masa pandemi Covid-19 disajikan pada Tabel 5.

Tabel 5 menunjukkan nilai Sig. (2tailed) adalah $0,000<0,05$, yang artinya terdapat perbedaan yang signifikan pada pendapatan usahatani kentang sebelum 
masa pandemi Covid-19 dan pada masa pandemi Covid-19 pada taraf nyata 5\%.

Tabel 5. Hasil Uji Paired Sample T-Test Pendapatan Usahatani Kentang

\begin{tabular}{cc}
\hline Uraian & $\begin{array}{c}\text { Pendapatan } \\
\text { Usahatani Kentang }\end{array}$ \\
\hline $\mathrm{N}$ & 44 \\
\hline $\mathrm{T}$ & 4,470 \\
\hline $\mathrm{Df}$ & 43 \\
\hline Sig. (2-tailed) & 0,000 \\
\hline
\end{tabular}

Sumber: Data Primer, 2020

\section{Analisis R/C}

Menurut Sumantri (2020), analisis R/C atau Return Cost Ratio berguna untuk memberikan informasi keuntungan relatif pada usahatani didasarkan pada perhitungan finansial. Nilai $\mathrm{R} / \mathrm{C}$ menunjukkan besarnya penerimaan usahatani yang diperoleh dengan pengeluaran usahatani dalam satu satuan biaya. Analisis R/C usahatani kentang sebelum masa pandemi Covid-19 dan pada masa pandemi Covid-19 disajikan pada Tabel 6.

Tabel 6. Analisis R/C Usahatani Kentang

\begin{tabular}{ccc}
\hline $\begin{array}{c}\text { Komponen } \\
\text { Analisis R/C }\end{array}$ & $\begin{array}{c}\text { Sebelum Masa } \\
\text { Pandemi } \\
\text { Covid-19 }\end{array}$ & $\begin{array}{c}\text { Masa } \\
\text { Pandemi } \\
\text { Covid-19 }\end{array}$ \\
\hline $\begin{array}{c}\text { Penerimaan } \\
\text { (Rp) }\end{array}$ & 160.046 .070 & 133.344 .450 \\
$\begin{array}{c}\text { Biaya Total } \\
\text { (Rp) }\end{array}$ & 115.384 .289 & 113.322 .274 \\
\hline Nilai R/C & $\mathbf{1 , 3 8}$ & $\mathbf{1 , 1 7}$ \\
\hline
\end{tabular}

Sumber: Data Primer, 2020

Berdasarkan Tabel 6, bahwa nilai

$\mathrm{R} / \mathrm{C}$ usahatani kentang sebelum masa pandemi Covid-19 adalah sebesar 1,38 lebih besar dari 1, maka dapat disimpulkan usahatani kentang petani tersebut menguntungkan dan layak untuk diusahakan. Hal ini menunjukkan bahwa dengan modal yang dikeluarkan sebesar Rp.1 akan menghasilkan pendapatan bagi petani kentang sebesar Rp.1,38, sedangkan nilai $\mathrm{R} / \mathrm{C}$ usahatani kentang pada masa pandemi Covid-19 adalah sebesar 1,17 lebih besar dari 1, maka dapat disimpulkan usahatani kentang petani tersebut menguntungkan dan layak untuk diusahakan. Hal ini menunjukkan bahwa dengan modal yang dikeluarkan sebesar Rp.1 akan menghasilkan pendapatan bagi petani kentang sebesar Rp.1,17.

\section{KESIMPULAN DAN SARAN}

Pendapatan kentang pada masa pandemi Covid-19 adalah sebesar Rp20.022.176/ha/MT lebih kecil dibandingkan sebelum masa pandemi Covid-19 yaitu sebesar Rp44.661.781/ha/MT, hal tersebut dikarenakan pada masa pandemi Covid19 terjadi pengurangan tenaga kerja, penggunaan bibit generasi selanjutnya sehingga menurunkan hasil produksi kentang, serta penurunan harga kentang yang mengakibatkan penurunan pendapatan petani kentang. Nilai R/C 
sebelum masa pandemi Covid-19 sebesar 1,38 dan pada masa pandemi Covid-19 sebesar 1,17 yang menunjukkan bahwa usahatani kentang di Kecamatan Kertasari layak dan menguntungkan.

Saran yang dapat diberikan adalah peningkatan intensifikasi tanaman dengan cara menerapkan penggunaan bibit yang unggul, pengolahan lahan yang baik, pemupukan yang tepat, pengendalian hama dan penyakit dan pengairan yang baik sehingga meminimalisir pengeluaran biaya produksi usahatani serta perlu adanya peran dan kebijakan pemerintah daerah untuk memperkuat posisi tawar petani dengan cara menyediakan sarana pemasaran kentang sehingga meminimalisir kerugian fluktuasi harga pada saat panen raya atau pada saat terjadinya peristiwa yang tak terduga seperti pandemi Covid-19.

\section{DAFTAR PUSTAKA}

Amarullah, M. R., Sudarsono, \& Amarillis, S. (2019). Produksi dan Budidaya Umbi Bibit Kentang (Solanum tuberosum L.) di Pangalengan, Bandung, Jawa. Bul. Agrohorti, 7(1), 93-99.

Apriadi, D., \& Saputra, A. Y. (2017). ECommerce Berbasis Marketplace Dalam Upaya Mempersingkat Distribusi Penjualan Hasil Pertanian. Rekayasa Sistem dan Teknologi Informasi, 1(2), 131-136.
Badan Pusat Statistik. (2018). Kabupaten Bandung Dalam Angka tahun 2018. BPS. Kabupaten Bandung.

Badan Pusat Statistik. (2019). Statistik Indonesia 2019. BPS.

Ernawati, Edison, \& Kusuma, N. P. (2015). Analisis pendapatan usahatani kentang di Kecamatan Jangkat Kabupaten Merangin . Sosio Ekonomika Bisnis, 18(1), 9399.

Food and Agriculture Organization (FAO). (2020). Food Security. Policy Brief, 1-4.

Herliani, D. R., Sumarjono, D., \& Setiawan, B. M. (2019). Analisis Pendapatan Usahatani Monokultur Kentang dan Tumpangsari Kentang-Carica Desa Sembungan Kecamatan Kejajar Kabupaten Wonosobo. SOCA: Jurnal Sosial Ekonomi Pertanian, 291-303.

Kementerian Pertanian. (2019). Statistik Konsumsi Pangan Tahun 2018. Jakarta: Sekretariat Jenderal Kementerian Pertanian.

Mardawati. (2013). Analisis Faktor Faktor yang Mempengaruhi Pendapatan Usahatani Kentang di Kabupaten Bener Meriah Provinsi Aceh. Agrium, Volume 10 Nomor 2, 38-42.

Muhibuddin. (2016). Inovasi Teknologi Pengambangan Kentang di Daratan Medium . Makassar: CV. Sah Media.

Mulyono, D., Syah, M. A., Sayekti, L., \& Hilman, Y. (2017). Kelas Benih Kentang (Solanum tuberosum L.) Berdasarkan Pertumbuhan, Produksi dan Mutu Produk. Jurnal Holtikultura, 27(2), 209-216.

Pemerintah Indonesia. 2020. Peraturan Menteri Kesehatan No.9 Tahun 2020 tentang Pedoman Pembatasan Sosial Berskala Besar. Lembaga Negeri RI Tahun 2020, Sekretariat Negara, Jakarta 
Puspasari, Hardjomidjojo, \& Sarma. (2013). Strategi Pengembangan. MANAJEMEN IKM: Jurnal Manajemen Pengembangan, 190198.

Rahmadona, L., Fariyani, A., \& Burhanuddin. (2015). Analisis Pendapatan Usahatani Bawang Merah di Kabupaten Majalengka. AGRISE volume XV No.2, 72 - 84.

Rahmah, S. A., \& Wulandari, E. (2020). Keragaan Produksi dan Harga Kentang di Kecamatan Pangalengan, Kabupaten Bandung. Pemikiran Masyarakat Ilmiah Berwawasan Agribisnis, 6(1), 265274.

Sukmawati, D., Sulisyowati, L., Karmana, M. H., \& Wikarta, E. K.
(2016). Fluktuasi Harga Cabai Merah Keriting (Capsicum annum L) Di Sentra produksi dan Pasar Induk (Tinjauan Harga Cabai Merah Keriting di Kecamatan Cikajang dan Pasar Induk Kramat Jati Jakarta). Mimbar Agribisnis, 1(2), 165-172.

Suratiyah, K. (2015). Ilmu Usahatani. Jakarta: Penebar Swadaya.

Yuliana. (2020). Corona virus disease (Covid-19) : Sebuah tinjauan literatur. Wellness and Healthy Magazine, 2(1), 187-192.

Yusuf, M. (2014). Metode Penelitian Kuantitatif, Kualitatif dan Penelitian Gabungan. Jakarta: Kencama. 